\section{From Growth Hormone-Releasing Peptides to Gbrelin: Discovery of New Modulators of GH Secretion}

revisão

Ana Maria J. Lengyel

Growth hormone (GH)-releasing hormone and somatostatin modulate $\mathrm{GH}$ secretion. A third mechanism has been discovered in the last decade, involving the action of $\mathrm{GH}$ secretagogues. Ghrelin is a new acylated peptide produced mainly by the stomach, but also synthesized in the hypothalamus. This compound increases both $\mathrm{GH}$ release and food intake. The relative roles of hypothalamic and circulating ghrelin on $\mathrm{GH}$ secretion are still unknown. Endogenous ghrelin might amplify the basic pattern of $\mathrm{GH}$ secretion, optimizing somatotroph responsiveness to $\mathrm{GH}$ releasing hormone. This peptide activates multiple interdependent intracellular pathways at the somatotroph, involving protein kinase $C$, protein kinase A and extracellular calcium systems. However, as ghrelin induces a greater release of $\mathrm{GH}$ in vivo, its main site of action is the hypothalamus. In this paper we review the available data on the discovery of ghrelin, the mechanisms of action and possible physiological roles of $\mathrm{GH}$ secretagogues and ghrelin on $\mathrm{GH}$ secretion, and, finally, the regulation of $\mathrm{GH}$ release in man after intravenous administration of these peptides. (Arq Bras Endocrinol Metab 2006;50/1:17-24)

Keywords: Ghrelin; GH; Growth hormone secretagogues; GHS

\title{
RESUMO
}

Dos Peptídeos Liberadores do Hormônio de Crescimento (HC) à Ghrelina: Descoberta de Novos Moduladores da Secreção de HC

A secreção de hormônio de crescimento (HC) é modulada pelo hormônio liberador de $\mathrm{HC}$ e pela somatostatina. Na ultima década foi descoberto um terceiro mecanismo de controle, envolvendo os secretagogos de HC. A ghrelina é um peptídeo acilado, descoberto recentemente, que é produzido no estômago, porém também é sintetizado no hipotálamo. Este peptídeo é capaz de liberar HC, além de aumentar a ingestão alimentar. A ghrelina endógena parece amplificar o padrão básico de secreção de HC, ampliando a resposta do somatotrófo ao hormônio liberador de HC. Este peptídeo estimula múltiplas vias intracelulares interdependentes no somatotrófo, envolvendo a proteína quinase $\mathrm{C}$, proteína quinase $\mathrm{A}$ e sistemas moduladores de cálcio extracelular. Entretanto, como a liberação de HC induzida pela ghrelina in vivo é mais acentuada que in vitro, seu local de atuação predominante é no hipotálamo. Nesse artigo apresentamos uma revisão sobre a descoberta da ghrelina, os dados existentes sobre os mecanismos de ação e possível papel fisiológico dos secretagogos de $\mathrm{HC}$ e da ghrelina na secreção de $\mathrm{HC}$ e, finalmente, os efeitos da administração endovenosa destes peptídeos sobre a secreção de HC no homem. (Arq Bras Endocrinol Metab 2006;50/1:17-24)

Descritores: Ghrelina; GH; Secretagogos de hormônio de crescimento; GHS

Division of Endocrinology, Federal University of São Paulo (UNIFESP/EPM), São Paulo, Brazil.
Recebido em 09/09/05

Revisado em 30/11/05 Aceito em 06/12/05 


\section{B}

Historical review EFORE THE IDENTIFICATION of the growth hormone-releasing hormone (GHRH), Bowers et al. (1) discovered a group of synthetic compounds with growth hormone $(\mathrm{GH})$-releasing properties (for review see ref. 2). These substances were developed from the met-enkephalin molecule, through theoretical calculations, computer modeling, chemical alterations and studies of biological activity. These small peptides were able to induce a weak GH release initially. Further chemical changes led to the synthesis of more potent compounds, including peptides such as GH releasing peptide-6 (GHRP-6), GHRP-2, hexarelin, and non-peptides, as MK-0677, which could be administered orally (2). In the last decade several studies were performed with these growth hormone secretagogues (GHS), especially with GHRP-6, and the obtained data have suggested that these compounds are modulators of $\mathrm{GH}$ release $(3)$. It was shown that GHS enhance $\mathrm{GH}$ secretion by different mechanisms than those activated by GHRH (for reviews see ref. 2,3 ), and these substances act through different receptors than those of GHRH, somatostatin or opioid peptides. In 1996 Howard et al. cloned the GHS receptor (GHS-R), which was mainly found in the anterior pituitary and in the hypothalamus, and also in other areas of the central nervous system (4). In 1999 Kojima et al. discovered the endogenous ligand for these orphan receptors in the stomach, and this new hormone was denominated ghrelin (from ghre, the IndoEuropean root of the word grow) (5). Ghrelin is also present in small amounts in the hypothalamus and is able to stimulate $\mathrm{GH}$ release in a potent manner $(5,6)$. This peptide is a new member of the brain-gut peptide family, and it acts in the control of appetite, an effect that is independent of GH release (for review see ref. $7,8)$. Ghrelin might have other actions, which are currently being investigated $(7,8)$. The discovery of ghrelin is an example of reverse pharmacology: the chemical synthesis of compounds, such as GHS, led to the discovery of the endogenous orphan receptor and, finally, to the isolation of its natural ligand.

\section{GHS receptor}

Howard et al. cloned the GHS receptor in 1996 and found that it belongs to the G-protein family. The GHS receptor has seven transmembrane spanning segments and three intracellular and extracellular loops (4). Two subtypes of receptors were discovered, GHS$\mathrm{Rla}$, which is active, and GHS-Rlb, a shorter isoform, which apparently does not have biological activity (4). It is likely that other subtypes might exist. The human
GHS-Rla has 366 aminoacids and is highly conserved in evolution. The active receptor was found in the anterior pituitary and in the hypothalamus, as well as in other regions of the central nervous system (4). GHS$\mathrm{Rla}$ is present in several hypothalamic areas, including the arcuate, ventromedial and paraventricular nuclei $(2,4)$. GHS-R might modulate biological rhythms, memory, mood, learning and appetite (2). In the pituitary GHS-R was found exclusively in somatotrophs (2). In knockout mice for GHS-Rla ghrelin fails to increase both $\mathrm{GH}$ release and food intake, indicating that both actions of ghrelin are dependent on this type of receptor. (9). GHS-Rla was also found in other tissues such as pancreas, heart, adrenal gland and the thyroid (10). It is interesting that GHS-Rlb, the inactive form, has a widespread distribution in peripheral tissues but its function has not been elucidated (10).

\section{Ghrelin}

In 1999 Kojima et al. surprisingly found a major increase in intracellular calcium concentrations with the addition of stomach extracts to an in vitro system of cells, which expressed GHS-Rla (5). Further studies led to the isolation of a 28 -aminoacid peptide with a fatty acid chain modification (n-octanoic acid), in the serine 3 residue. This hydrophobic compound, which is the first known natural bioactive peptide modified by an acyl acid, was called ghrelin. It was also found that ghrelin and the GHS, such as GHRP-6, have no structural similarity, which is quite intriguing (5). The post-translational fatty acid chain modification (noctanoyl residue) is essential for the biological activity of ghrelin, including GH release and appetite stimulation. Shorter fragments, with the first four to five residues, are also able to stimulate signal transduction of GHS-Rla in vitro when they have an intact acylated serine (7). However, the main circulating form is nonacylated ghrelin, which might have non-endocrine actions (5). Circulating nonacylated ghrelin levels are reduced by $80 \%$ after gastrectomy or gastric bypass in humans, demonstrating that this peptide is mainly produced in the stomach (11). It was recently shown that ghrelin crosses the blood brain barrier, and this transport occurs in both directions, from the central nervous system to blood and from blood to brain (12). It has also been shown that the acyl residue is important for this transport (12). The gene that encodes ghrelin is located on chromosome 3 in men and encodes a precursor of 117 aminoacids, with an $82 \%$ homology within species (5). Two isoforms of mRNA of prepro-ghrelin are produced by the same gene, by alternative splicing, in the stomach (5). One encodes 
the ghrelin precursor while the other encodes desGln ${ }^{14}$ ghrelin precursor, which has no glutamine on position 14 (5). This latter peptide has 27 aminoacids and is biologically active, but is present in small amounts. Therefore, the main active form is ghrelin. Ghrelin is found in the submucosal layer of the stomach fundus, in endocrine oxyntic cells (X/A), and also, in lower concentrations, in the gastrointestinal tract (7). Both ghrelin and its mRNA are present in the arcuate nucleus of the hypothalamus and in the pituitary gland $(5,10)$. At pituitary level it might act in autocrine or paracrine manner. It has been recently shown that ghrelin is expressed in lactotrophs, somatotrophs and thyrotrophs, cells that are dependent, for differentiation, on Pit 1 gene expression (8). Ghrelin is also able to modulate Pit- 1 transcription. Ghrelin has a widespread distribution and has been found in the lung, kidney, ovary, testis, placenta, among others, but its physiological role in these tissues remains to be elucidated (10). Because the localization of the biological active receptor (GHS-Rla) is not the same as the peptide, it is likely that other receptor subtypes might exist (10). Ghrelin is found in considerable amounts in circulation and this peptide has several actions apart from its modulatory role on $\mathrm{GH}$ release $(7,8)$. Ghrelin enhances food intake, by activation of NPY/AGRP (agouti-related protein) neurons in the hypothalamus, while leptin has the opposite effect $(7,8)$. Ghrelin is able to increase $\mathrm{GH}$ release both in animals and in men, and it also induces PRL, ACTH, cortisol and aldosterone secretion in vivo $(5,6,13,14)$. Ghrelin causes a slight increase in glucose levels and a reduction of circulating insulin (14). The discovery of ghrelin reinforced the concept of a third pathway of $\mathrm{GH}$ regulation $(2,3,7,8)$. However, the physiological role of this potent endogenous $\mathrm{GH}$-releasing peptide remains to be elucidated.

\section{GHS and Ghrelin: mechanism of action and possible physiological role on $\mathrm{GH}$ release}

GHS and ghrelin act both at hypothalamic and pituitary levels to modulate $\mathrm{GH}$ secretion (for reviews see ref. 3,7,8). These peptides stimulate the GHS-R in pituitary cells in vitro to induce $\mathrm{GH}$ release $(5)$. When GHRH is associated to GHS or ghrelin in vitro, an additive response is observed in most studies. However, when these peptides are administered together with GHRH in vivo, a synergistic effect on GH release is observed. This indicates that GHS and GHRH act through different mechanisms and suggests a main hypothalamic site of action of GHS $(6,14-16)$. This is confirmed by the lack of GH release after GHRP- 6 or ghrelin in hypothalamic pituitary disconnection, both in animals and in men $(17,18)$. It has been shown that an intact GHRH system is necessary for these actions to occur. Both $\mathrm{GH}$ pulsatility and $\mathrm{GH}$ responsiveness to ghrelin and GHS are decreased by the administration of antibodies against GHRH in rats (19). GHSinduced $\mathrm{GH}$ release is also blunted by a GHRH antagonist (20). GHS are not able to increase GH release in the lit/lit mouse, which has a GHRH receptor mutation, but they enhance hypothalamic $c$-fos expression, which is a marker of neuronal activity (21). GH response to GHS is inhibited in humans with $\mathrm{GHRH}$ receptor mutations, but the ACTH and PRL releasing effects are maintained, which suggests that the latter actions are mediated by the hypothalamus (22). The arcuate nucleus is the main target of ghrelin action, where it may bind and activate the GHS-R. GHS and ghrelin act centrally increasing electrical activity and $c$ fos expression in a subpopulation of cells in the arcuate nucleus, some of which are GHRH producing neurons (21). Moreover, one fourth of these GHRH neurons express the GHS-R, suggesting a direct effect of GHS in these cells (19). Ghrelin increases GHRH release from hypothalamic tissue in vitro, but this was not observed with GHS $(23,24)$. It has also been shown that GHS increase GHRH release into the pituitary portal system in sheep (25). GHS and ghrelin do not influence hypothalamic somatostatin release in most studies, both in vivo and in vitro (23-25). However, GHS act as functional somatostatin antagonists $(19,26)$. GHS increase the number of cells secreting $\mathrm{GH}$ and cause depolarization of the somatotroph, while somatostatin has opposite effects (26). Therefore, a model of action of GHS/ghrelin has been suggested, which would involve: 1) activation of GHRH producing neurons in the arcuate nucleus, with an increase in GHRH release; 2) amplification of the effect of GHRH at the somatotroph; 3) functional antagonism of somatostatin (2). GHS/ghrelin and GHRH bind to different pituitary receptors, and there is cross-talk between these receptors (for review see ref. 7). These peptides also stimulate different intracellular transduction pathways at the somatotroph. GHRH activates intracellular cyclic AMP and protein kinase A (PKA), while GHRP-6 stimulates protein kinase $\mathrm{C}(\mathrm{PKC})$, via inositol triphosphate signal transduction, with increase in intracellular calcium concentrations (figure 1) $(2,4)$. Interestingly, it has been recently shown that ghrelin activates multiple, interdependent, intracellular pathways in porcine somatotrophs, involving PKA, PKC and extracellular calcium systems. This effect is broader than the action of 


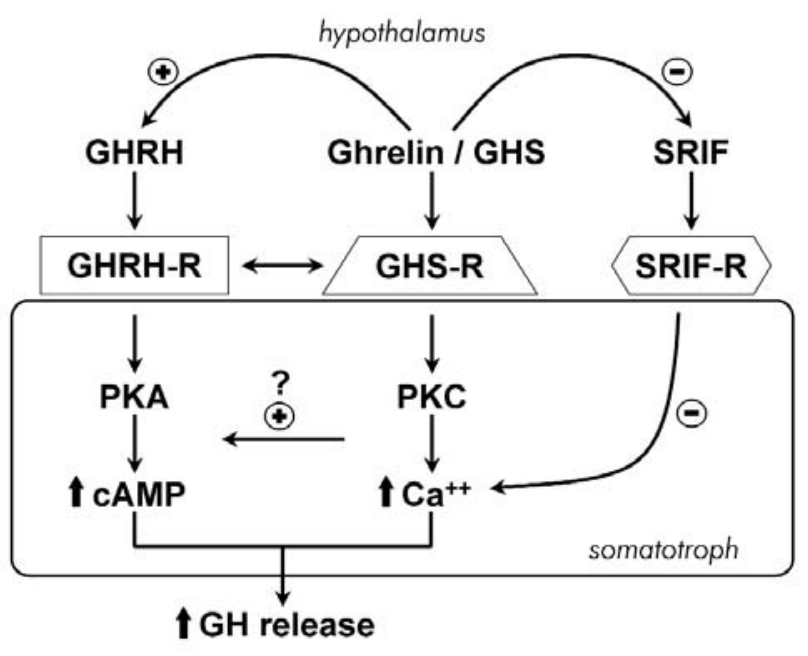

Figure 1. Schematic model of the possible interactions between GHRH, ghrelin/GHS and SRIF at hypothalamic and pituitary level.

most GHS, but similar to that described for GHRP-2 in this species (27). These results reinforce the possibility of cross-talk between these transduction pathways. However, the physiological role of these potent $\mathrm{GH}$ stimulators is still unclear. Controversial issues are how the hypothalamic peptide participates in GH modulation and whether circulating ghrelin has a role on pituitary GH secretion. In the rat ghrelin secretion occurs in a pulsatile manner, but has no correlation with GH pulses and is associated to food and sleep cycles (28). Circulating ghrelin levels are similar during $\mathrm{GH}$ peak and trough periods in the rat (29). Ghrelin immunoneutralization does not interfere with GH pulsatility, while GHRH antibodies block endogenous pulsatile GH release (30). In humans GHRH antagonist administration strongly inhibits $24 \mathrm{~h}$ GH secretion, but fails to affect circulating ghrelin levels (31). However, in rats, intracerebroventricular or peripheral administration of GHSR-1A antagonists attenuates spontaneous GH secretion, due to a decrease in pulse amplitude and mean GH levels (32-34). Interestingly, a missense mutation in the GHS receptor, which severely impaired ghrelin binding, was associated with a case of familial short stature (35). It has also been shown in healthy volunteers that circulating ghrelin is related to GH pulses, suggesting that ghrelin participates in the pulsatile regulation of $\mathrm{GH}$ secretion or that the two hormones are regulated in parallel (36). Therefore, endogenous ghrelin might amplify the basic pattern of GH secretion (32-34). This peptide may also have a physiological role in $\mathrm{GH}$ release by optimizing somatotroph responsiveness to GHRH
(37). Nevertheless, recent studies with ghrelin knockout animals failed to show a major effect on GH regulation (38). In contrast to predictions, these animals were not anorexic dwarfs (38). However, in transgenic models with decreased GHS-R mRNA expression in the arcuate nucleus, reduced GH and IGF-I levels were observed (39). Also, GHS-R knockout mouse had lower body weight and IGF-I values (40). These effects were only moderate, which is intriguing, as these peptides are quite potent GH stimulators. It has been previously suggested that the role of ghrelin on GH secretion might become more relevant during states of negative energy balance (30). However, further studies will be necessary to elucidate the physiological role of these peptides on GH secretion.

\section{Modulation of GH release by GHRP-6 and Ghrelin in man}

GHRP-6 and ghrelin increase GH release in a dose dependent manner, both in vivo and in vitro in several species, including man $(1,5,6,13,16)$. The GH releasing activity of ghrelin is similar to that of GHRH in vitro (5). However, iv ghrelin administration at a dose of $1 \mu \mathrm{g} / \mathrm{kg}$ increases GH release potently in man, and this response is higher than that obtained with GHRH, hexarelin and GHRP-6 $(13,14,41)$. This effect is not specific as an increase in PRL, ACTH, cortisol and aldosterone levels is also observed (14). Glucose levels increase and insulin values decrease after $i v$ administration of this peptide (14). These latter effects and the aldosterone stimulation are not seen with other GHS. When ghrelin or GHRP-6 are administered together with GHRH a synergistic effect is seen, but this is better observed with injections of ghrelin at low doses $(0,08$ and $0,2 \mu \mathrm{g} / \mathrm{kg})(14,16)$. The administration of GHRP-6 together with GHRH is an excellent test to diagnose GH deficiency in adults, but its usefulness in children is less clear (42). There is a highly reproducible response for GHS in normal subjects, studied in different occasions, differently than that observed for GHRH. There are no gender differences in the GH response to GHRP-6 and ghrelin $(3,15,43)$, but an age related decrease of responsiveness has been reported for both peptides $(3,15,43)$. It has been shown that obese subjects have blunted GH responses to GHRP-6 and ghrelin $(44,45)$. Ghrelininduced $\mathrm{GH}$ release is decreased by $55 \%$ in women with visceral adiposity and BMI of $362 \mathrm{~kg} / \mathrm{m}^{2}(45)$. Hyperglycemia, free fatty acids and somatostatin decrease GHRP- 6 and ghrelin-induced GH response $(46,47)$. Arginine was not able to alter GH responsiveness to ghrelin (48). The effect of cholinergic ago- 


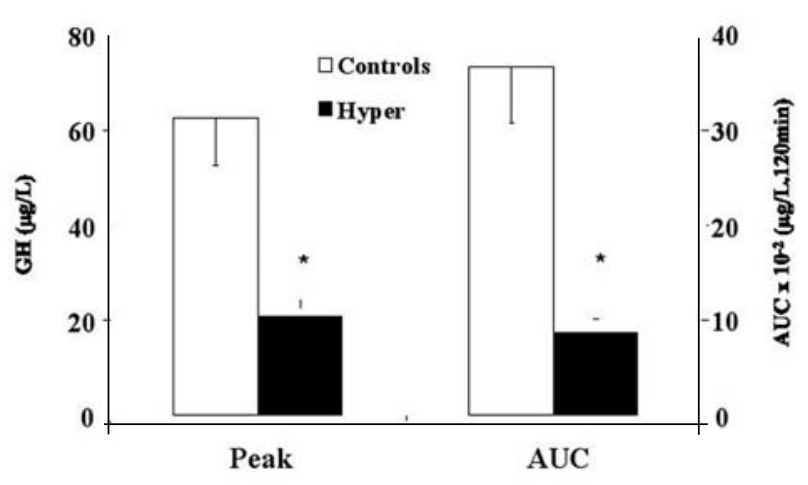

Figure 2. Mean $\mathrm{GH}$ peak and area under the curve (AUC) values after ghrelin administration in 6 hyperthyroid patients and 8 controls (mean $\pm \mathrm{SE}$; ${ }^{*} P<0,05$ ) (from ref. 58 ).

nists and antagonists on ghrelin-induced GH release is controversial. Piridostigmine failed to modify $\mathrm{GH}$ responsiveness to both ghrelin and GHRP-6 $(15,48)$. However, atropine blunted this response, but pirenzepine, a muscarinic receptor antagonist, was unable to alter GH release after ghrelin (49). These latter compounds only blunt GH response to GHRP-6, while they completely abolish GH response to GHRH (15). GH response to GHS was only attenuated by glucocorticoids and GH administration, which probably enhance hypothalamic somatostatin release $(50,51)$. In patients with Cushing's disease a blunted GH response to both GHRP- 6 and ghrelin has been reported by us and by others (52-55). In these patients GHS and ghrelin-induced ACTH and cortisol release is increased $(54,55)$. These latter effects could be due to a direct action of these peptides at GHS-R in the corticotroph adenoma or, alternatively, activation of hypothalamic AVP and probably, to a lesser extent, of CRH pathways (7). Interestingly, chronic glucocorticoid administration does not interfere with GHRP-6 induced GH release (53). It has been previously suggested that the time of exposure to hypercortisolism is important for the GH response to these peptides. In patients with adrenal insufficiency a $72 \mathrm{~h}$ withdrawal of glucocorticoid replacement therapy does not influence the GH responsiveness to GHRP-6 (57). We have shown that in hyperthyroidism there is a decrease in GH responsiveness to GHRH while GHRP-6-induced $\mathrm{GH}$ release is maintained, which could suggest that thyroid hormones interfere mainly with GHRHreleasing mechanisms (58). However, we have recently shown that there is a decrease in the GH response to ghrelin in these patients, suggesting that thyroid hormones might interfere with additional pathways of $\mathrm{GH}$ release activated by ghrelin (figure 2) (59). In type 1 diabetes mellitus GH response to GHRP- 6 and hexarelin is either normal or enhanced, demonstrating that hyperglycemia is unable to decrease GH release induced by these peptides, differently than in normal subjects (60). It has recently been shown that ghrelininduced GH release is decreased in anorexia nervosa, which is an unexpected finding as these patients have high GH levels and enhanced responses to GHRH and GHS (61). GH-releasing compounds could represent an alternative treatment in GH deficient states. However, these substances have failed to show benefit over GH therapy, despite the fact that they are more physiological, as they induce endogenous pulsatile GH release.

\section{CONCLUSION}

Ghrelin is a novel hormone secreted from the stomach to the circulation. This peptide is also produced in the hypothalamus and other tissues, with both endocrine and paracrine effects. The acyl modification of its molecule is essential for enhancement of $\mathrm{GH}$ release and stimulation of food intake. Several questions remain to be answered concerning the roles of circulating and hypothalamic ghrelin on GH release. Ghrelin might have a physiological role on pulsatile GH secretion, but further studies are necessary to clarify its precise role on $\mathrm{GH}$ modulation.

\section{ACKNOWLEDGEMENTS}

I am grateful to the postgraduate students who contributed to this work, to Prof. Dr. José G.H. Vieira for the constant laboratory support and to Aparecida Filomena Machado and Walkiria Miranda for assistance with the assays. Ana Maria J. Lengyel is a Senior Scientist of Conselho Nacional de Pesquisa (CNPq). This work was supported by FAPESP $(97 / 07689-0,02 / 03508-0$, 02/14118-9) and CNPq (300550/87-1).

\section{REFERENCES}

1. Bowers CY, Momany FA, Reynolds GA, Hong A. On the in vitro and in vivo activity of a new synthetic hexapeptide that acts on the pituitary to specifically release growth hormone. Endocrinology 1984;114:1537-45.

2. Smith RG, Van der Ploeg LHT, Howard AD, et al. Peptidomimetic regulation of growth hormone secretion. Endocr Rev 1997; 18:621-45.

3. Korbonits M, Grossman A. Growth hormone-releasing peptide and its analogues - novel stimuli to growth hormone release. Trends Endocrinol Metab 1995;6:43-9. 
4. Howard $A D$, Feighner $S D$, Cully DF, et al. A receptor in pituitary and hypothalamus that functions in growth hormone release. Science 1996;273:947-77.

5. Kojima M, Hosoda H, Date $Y$, Nakazato M, Matsuo H, Kangawa K. Ghrelin is a growth-hormone-releasing acylated peptide from stomach. Nature 1999;402:656-60.

6. Arvat E, DiVito L, Broglio F, Papotti M, Muccioli $G$, Dieguez $C$, et al. Preliminary evidence that ghrelin, the natural GH secretagogue (GHS)-receptor ligand, strongly stimulates $\mathrm{GH}$ secretion in humans. J Endocrinol Invest 2000:23:493-5.

7. Korbonits M, Goldstone A P, Gueorguiev M, Grossman AB. Ghrelin - a hormone with multiple functions. Front Neuroendocrinol 2004;25:27-68.

8. van der Lely AJ, Tschop M, Heiman ML, Ghigo E. Biological, physiological, pathophysiological, and pharmacological aspects of ghrelin. Endocr Rev 2004;25:426-57.

9. Sun $Y$, Wang $P$, Zheng $H$, Smith $R G$. Ghrelin stimulation of growth hormone release and appetite is mediated through the growth hormone secretagogue receptor. Proc Natl Acad Sci USA 2004; 101:4679-84.

10. Gnanapavan S, Kola B, Bustin SA, Morris DG, McGee P, Fairclough $P$, et al. The tissue distribution of the mRNA of ghrelin and subtypes of its receptor, GHS-R, in humans. J Clin Endocrinol Metab 2002;87:2988-91.

11. Cummings DE, Weigle DS, Frayo RS, Breen PA, Ma MK, Dellinger EP, et al. Plasma ghrelin levels after dietinduced weight loss or gastric bypass surgery. N Engl J Med 2002;346:1623-30.

12. Banks WA, Tschop M, Robinson SM, Heiman ML. Extent and direction of ghrelin transport across the blood-brain barrier is determined by its unique primary structure. J Pharmacol Exp Ther 2002;302:822-7.

13. Takaya K, Ariyasu H, Kanamoto N, Iwakura H, Yoshimoto A, Harada M, et al. Ghrelin strongly stimulates growth hormone release in humans. J Clin Endocrinol Metab 2000:85:4908-11

14. Arvat E, Maccario M, DiVito L, Broglio F, Benso A, Gottero $C$, et al. Endocrine activities of ghrelin, a natural growth hormone secretagogue (GHS), in humans: comparison and interactions with hexarelin, a nonnatural peptidyl $\mathrm{GHS}$, and GH-releasing hormone. J Clin Endocrinol Metab 2001;86:1169-74.

15. Peñalva $A$, Carballo $A$, Pombo $M$, Casanueva $F$, Dieguez C. Effect of growth hormone (GH)-releasing hormone $(\mathrm{GHRH})$, atropine, pyridostigmine, or hypoglycemia on GHRP-6-induced GH secretion in man. J Clin Endocrinol Metab 1993:76:168-71.

16. Hataya Y, Akamizu T, Takaya K, Kanamoto N, Ariyasu H, Saijo $\mathrm{M}$, et al. A low dose of ghrelin stimulates growth hormone $(\mathrm{GH})$ release synergistically with $\mathrm{GH}$-releasing hormone in humans. J Clin Endocrinol Metab 2001:86:4552-5.

17. Popovic V, Damjanovic S, Micic D, Djurovic M, Dieguez C, Casanueva FF. Blocked growth hormone-releasing peptide (GHRP-6)-induced GH secretion and absence of the synergic action of GHRP-6 plus GH-releasing hormone in patients with hypothalamopituitary disconnection: evidence that GHRP-6 main action is exerted at the hypothalamic level. J Clin Endocrinol Metab 1995:80:942-7.
18. Popovic V, Miljic D, Micic D, Damjanovic S, Arvat E, Ghigo E, et al. Ghrelin main action on the regulation of growth hormone release is exerted at hypothalamic level. J Clin Endocrinol Metab 2003;88:3450-3.

19. Tannenbaum GS, Bowers CY. Interactions of growth hormone secretagogues and growth hormone-releasing hormone/somatostatin. Endocrine 2001;14:21-7.

20. Pandya N, Mott-Friberg R, Bowers CY, Barkan AL, Jaffe $\mathrm{CA}$. Growth hormone (GH)-releasing peptide-6 requires endogenous hypothalamic GH-releasing hormone for maximal GH stimulation. J Clin Endocrinol Metab 1998;83:1 186-9.

21. Dickson SL, Doutrelant-Viltart O, Leng G. GH-deficient $d w / d w$ rats and lit/lit mice show increased Fos expression in the hypothalamic arcuate nucleus following systemic injection of GH-releasing peptide-6. J Endocrinol $1995 ; 146: 519-26$

22. Maheshwari H, Rahim A, Rahim A, Shalet S, Baumann G. Selective lack of growth hormone $(\mathrm{GH})$ response to the $\mathrm{GH}$-releasing peptide hexarelin in patients with $\mathrm{GH}$ releasing hormone receptor deficiency. J Clin Endocrinol Metab 1999:84:956-9.

23. Wren AM, Small CJ, Fribbens CV, Neary NM, Ward HL, Seal LJ, et al. The hypothalamic mechanisms of the hypophysiotropic action of ghrelin. Neuroendocrinology 2002:76:316-24.

24. Korbonits $M$, Little JA, Forsling ML, Tringali $G$, Costa A, Navarra $P$, et al. The effect of growth hormone secretagogues and neuropeptide $Y$ on hypothalamic hormone release from acute rat hypothalamic explants. J Neuroendocrinol 1999;11:521-8.

25. Guillaume V, Magnan E, Cataldi M, Dutour A, Sauze N Renard $M$, et al. Growth hormone (GH)-releasing hormone secretion is stimulated by a new GH-releasing hexapeptide in sheep. Endocrinology 1994; 135:1073-6.

26. Goth MI, Lyons CE, Canny BJ, Thorner MO. Pituitary adenylate cyclase activating polypeptide, growth hormone $(\mathrm{GH})$-releasing peptide and $\mathrm{GH}$-releasing hormone stimulate $\mathrm{GH}$ release through distinct pituitary receptor. Endocrinology 1992;130:939-44.

27. Malagon MM, Luque RM, Ruiz-Guerrero E, RodriguezPacheco F, Garcia-Navarro S, Casanueva FF, et al. Intracellular signaling mechanisms mediating ghrelinstimulated growth hormone release in somatotropes. Endocrinology 2003; 144:5372-80.

28. Tolle $V$, Bassant $M H$, Zizzari $P$, Poindessous-Jazat $F$, Tomasetto C, Epelbaum J, et al. Ultradian rhythmicity of ghrelin secretion in relation with $\mathrm{GH}$, feeding behavior, and sleep-wake patterns in rats. Endocrinology 2002; 143:1353-61.

29. Okimura Y, Ukai K, Hosoda H, Murata M, Iguchi G, lida K, et al. The role of circulating ghrelin in growth hormone (GH) secretion in freely moving male rats. Life Sci 2003:72:2517-24.

30. Tannenbaum GS, Epelbaum J, Bowers CY, Interrelationship between the novel peptide ghrelin and somatostatin/growth hormone-releasing hormone in regulation of pulsatile growth hormone secretion. Endocrinology 2003; 144:967-74.

31. Barkan AL, Dimaraki EV, Jessup SK, Symons KV, Ermolenko M, Jaffe CA. Ghrelin secretion in humans is 
sexually dimorphic, suppressed by somatostatin, and not affected by the ambient growth hormone levels. J Clin Endocrinol Metab 2003:88:2180-4.

32. Halem HA, Taylor JE, Dong JZ, Shen Y, Datta R, Abizaid $A$, et al. Novel analogs of ghrelin: physiological and clinical implications. Eur J Endocrinol 2004;151 (suppl. 1):S71-5.

33. Zizzari P, Halem H, Taylor J, Dong JZ, DattaR, Culler MD, et al. Endogenous ghrelin regulates episodic growth hormone $(\mathrm{GH})$ secretion by amplifying $\mathrm{GH}$ pulse amplitude: evidence from antagonism of the $\mathrm{GH}$ secretagogueRla receptor. Endocrinology 2005; 146:3836-42.

34. Tannenbaum GS, Samia M, Chen Q, Bowers CY. Antagonism of the growth hormone secretagogue receptor unmasks a role for ghrelin in maintaining high $\mathrm{GH}$ pulse amplitude under physiological conditions. Endo Soc 87th Ann Meet 2005; San Diego, USA, June 4-7.

35. Pantel J, Cabrol S, Nivot S. Familial short stature associated with a mutation in the growth hormone secretagogue receptor (GHSR). Endo Soc 86th Ann Meet 2004: New Orleans, USA, June 16-19.

36. Koutkia P, Canavan B, Breu J, Johnson ML, Grinspoon SK. Nocturnal ghrelin pulsatility and response to growth hormone secretagogues in healthy men. Am J Physiol Endocrinol Metab 2004;287:E506-12.

37. Kamegai J, Tamura H, Shimizu T, Ishii S, Tatsuguchi A, Sugihara $\mathrm{H}$, et al. The role of pituitary ghrelin in growth hormone (GH) secretion: GH-releasing hormone-dependent regulation of pituitary ghrelin gene expression and peptide content. Endocrinology 2004; 145:3731-8.

38. Sun Y, Ahmed S, Smith RG. Deletion of ghrelin impairs neither growth nor appetite. Mol Cell Biol 2003; 23:7973-81.

39. Shuto $\mathrm{Y}$, Shibasaki T, Otagiri A, Kuriyama $\mathrm{H}$, Ohata $\mathrm{H}$ Tamura $\mathrm{H}$, et al. Hypothalamic growth hormone secretagogue receptor regulates growth hormone secretion, feeding, and adiposity. J Clin Invest 2002; 109:1429-36.

40. Sun $Y$, Wang $P$, Zheng $H$, Smith RG. Ghrelin stimulation of growth hormone release and appetite is mediated through the growth hormone secretagogue receptor. Proc Natl Acad Sci USA 2004; 101:4679-84.

41. Peino R, Baldelli R, Rodriguez-Garcia J, RodriguezSegade S, Kojima M, et al. Ghrelin-induced growth hormone secretion in humans. Eur J Endocrinol 2000; 143:R1 1-4.

42. Popovic V, Leal A, Micic D, Koppeschaar HPF, Torres E, Paramo $\mathrm{C}$, et al. $\mathrm{GH}$-releasing hormone and $\mathrm{GH}$-releasing peptide-6 for diagnostic testing in $\mathrm{GH}$-deficient adults. Lancet 2000;356:1137-42.

43. Broglio F, Benso A, Castiglioni C, Gottero C, Prodam F, Destefanis $\mathrm{S}$, et al. The endocrine response to ghrelin as a function of gender in humans in young and elderly subjects. J Clin Endocrinol Metab 2003;88: 1537-42.

44. Cordido F, Peñalva A, Dieguez C, Casanueva FF. Massive growth hormone $(\mathrm{GH})$ discharge in obese subjects after the combined administration of $\mathrm{GH}$-releasing hormone and GHRP-6: evidence for a marked somatotroph secretory capability in obesity. J Clin Endocrinol Metab 1993:76:819-23

45. Tassone F, Broglio F, Destefanis S, Rovere S, Benso A, Gottero $C$, et al. Neuroendocrine and metabolic effects of acute ghrelin administration in human obesity. J Clin Endocrinol Metab 2003;88:5478-83.

46. Maccario M, Arvat E, Procopio M, Gianotti L, Grottoli S, Imbimbo BP, et al. Metabolic modulation of the growth hormone-releasing activity of hexarelin in man. Metabolism 1995;44:134-8.

47. DiVito L, Broglio F, Benso A, Gottero C, Prodam F, Papotti $\mathrm{M}$, et al. The $\mathrm{GH}$-releasing effect of ghrelin, a natural $\mathrm{GH}$ secretagogue, is only blunted by the infusion of exogenous somatostatin in humans. Clin Endocrinol 2002; $56: 643-8$.

48. Broglio F, Benso A, Gottero C, Prodam F, Grottoli S, Tassone $F$, et al. Effects of glucose, free fatty acids or arginine load on the GH-releasing activity of ghrelin in humans. Clin Endocrinol 2002;57:265-71.

49. Maier C, Schaller G, Buranyi B, Nowotny P, Geyer G, Wolzt $M$, et al. The cholinergic system controls ghrelin release and ghrelin-induced growth hormone release in humans. J Clin Endocrinol Metab 2004;89:4729-33.

50. Gertz BJ, Sciberras DG, Yogendran L, Christie K, Bador K, Krupa D, et al. L-692,429, a nonpeptide growth hormone $(\mathrm{GH})$ secretagogue, reverses glucocorticoid suppression of GH secretion. J Clin Endocrinol Metab 1994;79:745-9.

51. Arvat E, DiVito L, Gianotti L, et al. Mechanisms underlying the negative growth hormone $(\mathrm{GH})$ autofeedback on the $\mathrm{GH}$-releasing effect of hexarelin in man. Metabolism 1997:46:83-8.

52. Leal-Cerro A, Pumar A, Garcia-Garcia E, Dieguez C, Casanueva FF. Inhibition of growth hormone release after the combined administration of GHRH and GHRP6 in patients with Cushing's syndrome. Clin Endocrinol 1994:41:649-54.

53. Borges MH, DiNinno FB, Lengyel AM. Different effects of growth hormone releasing peptide (GHRP-6) and $\mathrm{GH}$ releasing hormone on $\mathrm{GH}$ release in endogenous and exogenous hypercortisolism. Clin Endocrinol 1997; 46:713-8

54. Leal-Cerro A, Torres E, Soto A, Dios E, Deghenghi R, Arvat $E$, et al. Ghrelin is no longer able to stimulate growth hormone secretion in patients with Cushing's syndrome but instead induces exaggerated corticotropin and cortisol responses. Neuroendocrinology 2002;76:390-6.

55. Correa-Silva SR, Nascif SO, Silva MR, Senger MH, Miranda WL, Machado AF, et al. Decreased GH secretion and enhanced ACTH and cortisol release after ghrelin administration in Cushing's disease: comparison with GHRP-6. Proc 12th Intern Congr Endocrinol 2004. Lisbon, Portugal, August 31- September 4.

56. Arvat E, Giordano R, Ramunni J, Arnaldi G, Colao A, Deghenghi $\mathrm{R}$, et al. Adrenocorticotropin and cortisol hyperresponsiveness to hexarelin in patients with Cushing's disease bearing a pituitary microadenoma, but not in those with macroadenoma. J Clin Endocrinol Metab 1998:83:4207-11

57. Pinto AC, Silva MR, Martins MR, Brunner E, Lengyel AM. Effects of short-term glucocorticoid deprivation on growth hormone $(\mathrm{GH})$ response to $\mathrm{GH}$-releasing peptide-6: studies in normal men and in patients with adrenal insufficiency. J Clin Endocrinol Metab 2000:85: 1540-4

58. Ramos-Dias JC, Pimentel-Filho F, Reis AF, Lengyel AM. Different growth hormone $(\mathrm{GH})$ response to GH-releas- 
ing peptide and $\mathrm{GH}$-releasing hormone in hyperthyroidism. J Clin Endocrinol Metab 1996;81:1343-6.

59. Nascif SO, Correa-Silva S, Silva MR, Senger MH, Lengyel AM. The effects of ghrelin on GH, ACTH and cortisol release in thyrotoxicosis. Proc 12th Intern Congr Endocrinol 2004. Lisbon, Portugal, August 31-September 4.

60. Weffort RFVB, Ramos-Dias JC, Chipoch C, Lengyel AM. Growth hormone $(\mathrm{GH})$ response to $\mathrm{GH}$-releasing peptide-6 in patients with insulin-dependent diabetes mellitus. Metabolism 1997:46:706-10.

61. Broglio F, Gianotti L, Destefanis S, et al. The endocrine response to acute ghrelin administration is blunted in patients with anorexia nervosa, a ghrelin hypersecretory state. Clin Endocrinol 2004;60:592-9.

\section{Endereço para correspondência:}

Ana Maria J. Lengyel

Div. Endocrinology, UNIFESP/EPM

R. Pedro de Toledo 910

04039-002 São Paulo, Brazil

Fax: (1 1) 5574-8432

E-mail: amlengyel@rocketmail.com 